\title{
Investigational Product Certificate of Analysis
}

National Cancer Institute

\section{Source}

National Cancer Institute. Investigational Product Certificate of Analysis. NCI Thesaurus.

Code C115473.

Official records stating an investigational product is the correct identity, purity and strength for use in the intended clinical trial. 